\title{
Atrazine degradation patterns: the role of straw cover and herbicide application history
}

\author{
Daniela Piaz Barbosa Leal ${ }^{1 *}$, Deborah Pinheiro Dick ${ }^{2} \odot$, Anna Meike Stah ${ }^{3 \oplus}$, Stephan Köppchen ${ }^{3 \oplus}$, Peter Burauel ${ }^{3 \oplus}$
}

\author{
1Universidade Federal do Rio Grande do Sul - Depto. de \\ Solos, Av. Bento Gonçalves, 7712 - 91540-000 - Porto \\ Alegre, RS - Brasil. \\ 2Universidade Federal do Rio Grande do Sul/nstituto de \\ Química, Av. Bento Gonçalves, 9500 - 91501-970 - Porto \\ Alegre, RS - Brasil. \\ ${ }^{3}$ Forschungszentrum Jülich GmbH - IBG-3: Agrosphere \\ Institute, Wilhelm-Johnen-Straße - 52425 - Jülich - Germany. \\ ${ }^{*}$ Corresponding author <d.barbosa.leal@outlook.com>
}

Edited by: Lincoln Zotarelli

Received June 27, 2017

Accepted August 29, 2017

\begin{abstract}
In Brazil, atrazine (ATZ) is widely applied to maize (Zea mays L.) fields for weed control. The presence of ATZ and its metabolites in soil and water matrices has become a matter of some concern for governmental authorities as well as for society at large. This study evaluated the patterns of ATZ degradation (mineralization, extractable and non-extractable ATZ residues, and metabolite formation) in a Brazilian Typic Paleudult. Soil samples from a cultivated area under a no-tillage system with a history of ATZ application were incubated with ${ }^{14} \mathrm{C}-\mathrm{ATZ}$ in both the presence and absence of straw cover on the soil surface, and the evolved ${ }^{14} \mathrm{CO}_{2}$ was determined by liquid scintillation. Samples from an area with native vegetation, adjacent to the cultivated area, were also incubated as a control. A higher mineralization of ATZ was observed in the cultivated soil (> $85 \%$ ) in comparison with the native soil (10\%) after 85 days of incubation. In addition to the higher mineralization and hydroxyatrazine (HA) formation, a rapid decrease in the water-extractable residues was observed in the cultivated soil. When the cultivated soil was covered with straw, mineralization was reduced by up to $30 \%$ although a small amount of remobilization to the soil occurred within the 85 days. Straw cover hindered the degradation of ATZ in cultivated soils; whereas an accelerated biodegradation was due to repeated applications of ATZ, which may have selected microbiota more skilled at biodegrading the herbicide.

Keywords: atrazine mineralization, sorption, metabolites, no-tillage
\end{abstract}

\section{Introduction}

Brazil is one of the world's largest maize (Zea mays L.) producers and it was estimated that production for the 2016/2017 crop season would reach 92 million tons, which is mainly cultivated under no-tillage (CONAB, 2017; Corbeels et al., 2016). The herbicide atrazine (ATZ) (2-chloro-4-(ethylamino)-6-(isopropylamino)-s-triazine), a broadleaf herbicide, is widely applied in maize plantations in Brazil as well as in other American countries although it has been banned in Europe since 2004 (Mudhoo and Garg, 2011; Santos et al., 2015; Sass and Colangelo, 2006). Due to its physical-chemical properties, ATZ is considered a pollutant of some environmental concern. Soil organic matter is the main soil sorbent for ATZ, followed, to a lesser extent, by the inorganic fraction, which may represent a barrier to its downward translocation of the profile (Dick et al., 2010). Concentrations of ATZ above $2 \mu \mathrm{g} \mathrm{L}^{-1}$, the limit allowed by the Brazilian regulation system (Conama, 2005), and relevant concentrations of its metabolites, have been found in a number of water matrices in different regions in Brazil (Casara et al., 2012; Nogueira et al., 2012; Santos et al., 2015). Enhanced biodegradation of pesticides, due to adaptation of soil microorganisms promoted by repeated application of the chemical compound, results in a rapid use of the molecule as a carbon source of energy and/or nutrients (Arbeli and Fuentes, 2007). Agricultural soils with detected enhanced $s$-triazine degradation are to be found worldwide and the consequent short-term persistence of ATZ may mitigate its potential risk for contamination. However, it also reduces its biocide efficiency (Krutz et al., 2010).
Previous laboratory and field studies on Brazilian soils evaluated the patterns of ATZ dissipation (Aquino et al., 2013; Correia et al., 2007) while others considered the role of straw (covering or mixed into the soil (Amadori et al., 2016; Araldi et al., 2015; Silva et al., 2016) or the extent of enhanced ATZ degradation (Bonfleur et al., 2010; Martinazzo et al., 2010). Nevertheless, a simultaneous study of ATZ degradation patterns with radiolabeled herbicide, focusing on the role of the straw cover simulating a no-tillage system has not so far been reported for Brazilian agricultural soils. Thus, the role of the straw cover on the dissipation kinetics of ATZ in a Typic Paleudult with a history of ATZ application over 20 years under no-tillage was investigated. Simultaneously, ${ }^{14} \mathrm{C}$-ATZ mineralization, extractable and non-extractable ${ }^{14} \mathrm{C}$-ATZ residues, and metabolite formation were evaluated in both soil and straw compartments.

\section{Materials and Methods}

\section{Field history, soil and straw sampling}

The experimental field was located at Eldorado do Sul, in the state of Rio Grande do Sul, Brazil $\left(30^{\circ} 50^{\prime} 52^{\prime \prime}\right.$ S; $51^{\circ} 38^{\prime} 08^{\prime \prime} \mathrm{W}$ ) at $46 \mathrm{~m}$ above sea level, on a Typic Paleudult (sandy clay loam soil). The soil particle size distribution contained $496 \mathrm{~g} \mathrm{~kg}^{-1}$ of sand, $291 \mathrm{~g} \mathrm{~kg}^{-1}$ of silt, and $213 \mathrm{~g} \mathrm{~kg}^{-1}$ of clay, with the clay fraction composed mainly of kaolinite, hematite and goethite (Dick et al., 2010). The climate is classified as humid subtropical (Cfa) in accordance with Köppen's climate classification (Alvares et al., 2013). The samples referred to as "cultivat- 
ed soil" were collected in an area which has been under no-tillage with crop rotation (maize/oat (Avena sativa L.)/ soybean (Glycine $\max (\mathrm{L}$.$) Merr)) since 1991$ and which has been treated for the past 20 years with commercial ATZ at agronomically recommended dosages (1.0 - 1.25 $\mathrm{kg}$ of active ingredient ha ${ }^{-1}$ ) to control annual weeds. The predominant weed species found in the experimental field were Brachiaria plantaginea, Bidens spp. and Sida rhombifolia. ATZ field application was carried out every other year and the last application was in Oct 2010, resulting in a total of 10 applications within 20 years. The samples referred to as "native soil" were collected in an adjacent area under field grass, approximately $50 \mathrm{~m}$ away from the "cultivated soil", which had no history of agricultural use of ATZ. However, the potential risk of drift caused by the ATZ spraying during its application in the cultivated soil should not be neglected. Both areas were part of a long-term experiment and approximately $2 \mathrm{~kg}$ of soil samples were collected from each site. Samples were taken randomly in triplicate from the upper $10 \mathrm{~cm}$ soil layer in Aug 2011 and were subsequently air-dried and sieved $(2 \mathrm{~mm})$. The main characteristics of the cultivated and native soils are given in Table 1. Samples of dry oat straw were collected in an adjacent cultivated area under no-tillage and were kept in plastic bags. Oat was chosen to simulate soil cover because it is commonly used as a winter cover crop in that region, and is usually desiccated with glyphosate (1.8 - $2.4 \mathrm{~kg}$ of active ingredient $\mathrm{ha}^{-1}$. The oat straw contained $39 \% \mathrm{C}$, $6 \% \mathrm{H}$ and $1 \% \mathrm{~N}$ on air-dry matter.

\section{ATZ mineralization}

Incubation experiments were conducted for 85 days in hermetically sealed $250 \mathrm{~mL}$ Duran glass bottles (70 $\mathrm{mm}$ diameter and $143 \mathrm{~mm}$ height) in a dark room with a controlled temperature of $20 \pm 2{ }^{\circ} \mathrm{C}$, in Jülich, Germany. Dry soil samples were initially wetted to $20 \%$ of the soil maximum water-holding capacity (WHCmax) and kept in the dark at $24 \pm 2{ }^{\circ} \mathrm{C}$ for $24 \mathrm{~h}$ to reactivate soil microbiota. A spiking solution was prepared using technical-grade ATZ (99 \% chemical purity) and ring- ${ }^{14} \mathrm{C}$ labeled ATZ (99\% radiochemical purity, 6.4 $\mathrm{MBq}^{-1}$ )

Table 1 - Characteristics of the Typic Paleudult at the time of sampling.

\begin{tabular}{|c|c|c|}
\hline \multirow{2}{*}{ Characteristics } & \multicolumn{2}{|c|}{ Typic Paleudult } \\
\hline & Cultivated & Native \\
\hline Water-holding capacity (\%) & 53 & 51 \\
\hline Organic carbon content (\%) & 3.8 & 4.1 \\
\hline Soil $\mathrm{pH}\left(\mathrm{H}_{2} \mathrm{O}\right)$ & 5.0 & 5.3 \\
\hline Clay $(\%)$ & 22 & 14 \\
\hline Atrazine $(A T Z)^{*}\left(\mu g \mathrm{~kg}^{-1}\right)$ & 1.5 & n.d. \\
\hline Hydroxyatrazine $(\mathrm{HA})^{*}\left(\mu \mathrm{g} \mathrm{kg}^{-1}\right)$ & 1.7 & 0.3 \\
\hline Desethylatrazine $(D E A)^{\star}\left(\mu g \mathrm{~kg}^{-1}\right)$ & n.d. & n.d. \\
\hline Deisopropylatrazine (DIA)* $\left(\mu \mathrm{g} \mathrm{kg}{ }^{-1}\right)$ & n.d. & n.d. \\
\hline
\end{tabular}

in ethanol (Merck), and its application to the incubation vessels followed two different methods, herein referred to as "mixing" and "dropping". By the mixing application method, the spiking solution was added to $10 \mathrm{~g}$ of an air-dried ground aliquot of soil sample, and ethanol contained in the solution was further evaporated at an experimental temperature. At $20{ }^{\circ} \mathrm{C}$ the vapor pressure of ethanol is $5.8 \mathrm{kPa}$ and that of ATZ $0.410^{-8} \mathrm{kPa}$ (NCBI, 2017), thus the loss of ATZ during ethanol evaporation was negligible. Subsequently, these $10 \mathrm{~g}$ spiked aliquots were thoroughly mixed with $400 \mathrm{~g}$ (dry weight) of nonspiked sample (cultivated soil and native soil). Ten subsamples of $0.5 \mathrm{~g}$ dry weight from each soil treatment were combusted to determine total radioactivity and monitor the homogeneous distribution of ATZ in the soil. The initial herbicide concentration was $0.9 \mathrm{mg} \mathrm{kg}^{-1}$, and initial radioactivity was $1505 \mathrm{kBq} \mathrm{kg}^{-1}$ soil. Using the dropping application method, the spiking solution was applied in small drops $(0.5 \mu \mathrm{L})$ directly to the straw or soil surface to simulate herbicide application by spraying in the field.

Incubation experiments were performed in a complete randomized design with three replicates. To evaluate the occurrence of enhanced ATZ degradation in the cultivated soil, Microcosm 1 and Microcosm 2 were prepared with cultivated soil and native soil, respectively, and ${ }^{14} \mathrm{C}$-ATZ solution was applied as per the mixing method. To evaluate the effect of straw cover on ATZ dissipation in the cultivated soil, Microcosm 3 and Microcosm 4 were prepared with this soil in the presence and absence of straw cover, respectively, and ${ }^{14} \mathrm{C}$-ATZ solution was applied by dropping. An extra microcosm (Microcosm 5) with solely straw was also performed (Table 2). The final soil moisture content of each flask was adjusted to $50 \%$ WHCmax and maintained during the 85 days of incubation by checking the weight, and adding distilled water by dropping. To monitor the evolving ${ }^{14} \mathrm{CO}_{2}$, a glass vial containing $1.5 \mathrm{~mL}$ of $2.0 \mathrm{~mol}$ $\mathrm{L}^{-1} \mathrm{NaOH}$ solution was placed in a cap holder inside the incubating flasks. $\mathrm{NaOH}$ solution was periodically removed and replaced by fresh solution on a daily basis during the first seven days of incubation, then every two to four days during the first 30 days of incubation, and weekly thereafter. The sampling time of the trapped ${ }^{14} \mathrm{CO}_{2}$ was based on previous ${ }^{14} \mathrm{C}$-ATZ mineralization assays (Jablonowski et al., 2010, 2013; Martinazzo et al., 2010), which showed a pattern of an increasing and rap-

Table 2 - Treatments description.

\begin{tabular}{|c|c|c|c|}
\hline Microcosm & Soil ${ }^{1}$ & Straw cover ${ }^{2}$ & ATZ application \\
\hline 1 & Cultivated & Absence & Mixing with the soil \\
\hline 2 & Native & Absence & Mixing with the soil \\
\hline 3 & Cultivated & Presence & Dropping \\
\hline 4 & Cultivated & Absence & Dropping \\
\hline 5 & Absence & Presence & Dropping \\
\hline
\end{tabular}
$\mathrm{cm}$ high. 
idly evolved ${ }^{14} \mathrm{CO}_{2}$ at the beginning of the incubation, followed by a plateau. Trapped ${ }^{14} \mathrm{CO}_{2}$ was determined by a liquid scintillation counter (LSC) using a $10 \mathrm{~mL}$ scintillation cocktail and $4 \mathrm{~mL}$ deionized water $(18.0 \mathrm{M} \Omega \mathrm{cm}$ ) per sample.

\section{Extractable and non-extractable ATZ residues}

Extractable and non-extractable radioactivity and metabolite formation were monitored on days $0,9,16$, 30 and 85 of incubation. Three fractions of ${ }^{14} \mathrm{C}$ activity were determined as: (1) extractable by water, (2) extractable by accelerated solvent extraction (ASE), and (3) non-extractable residues.

\section{Water extraction}

The entire soil sample contained in each flask from Microcosms 1, 2, 3 and 4 was extracted once with deionized water in a soil/solution ratio of $1: 8$, in accordance with Jablonowski et al. (2008). The whole straw sample from Microcosms 3 and 5 was manually collected using forceps and subsequently extracted once with $60 \mathrm{~mL}$ of deionized water. The soil and straw suspensions were shaken on a horizontal shaker at room temperature for $6 \mathrm{~h}$ at $150 \mathrm{rpm}$. The soil suspension was centrifuged at $10000 \times \mathrm{g}$ for $90 \mathrm{~min}$. The soil and straw supernatants ( $80 \mathrm{~mL}$ and $40 \mathrm{~mL}$, respectively) were filtered through a $0.45 \mu \mathrm{m}$ membrane and their volume measured. The filtrate was analyzed for desorbed ${ }^{14} \mathrm{C}$ activity via LSC, and for ATZ and its metabolites via liquid chromatography and mass spectrometry (LC-MS/MS). The filters used in this procedure were combusted, and the radioactivity detected was considered in the final mass balance. Water-extracted soil and straw samples were freezedried and ground in a mortar.

\section{Accelerated solvent extraction}

The ASE-extraction was based on the method described by Jablonowski et al. (2009). Following water extraction, $10 \mathrm{~g}$ subsamples of ground soil from Microcosms 1, 2, 3 and 4 were extracted four times in succession using an ASE 200 system. All the soil subsamples (10 g) were transferred to $11 \mathrm{~mL}$ stainless steel ASE cells, and the remaining space above the samples filled with quartz (Merck) to reduce the extract volume and avoid clogging of the ASE steel filter lid. A methanol (Merck)/ water solution $(4: 1 \mathrm{v} / \mathrm{v})$ was used as a solvent for extraction. Previous results have shown that this mixture yields higher residual ${ }^{14} \mathrm{C}$-activity in the extracts than pure methanol (Gan et al., 1999; Jablonowski et al., 2009). The extraction was performed at $135{ }^{\circ} \mathrm{C}$ under 100 bar with a flush volume of $60 \%$ of extraction cell volume. The heat-up and static times were $7 \mathrm{~min}$ and $15 \mathrm{~min}$, respectively. Straw samples from Microcosms 3 and 5 were not ASE-extracted due to the deterioration in condition after water extraction. Water- and ASEextracted ${ }^{14} \mathrm{C}$ activity was detected by LSC in triplicate. The water-extracted sample $(5 \mathrm{~mL})$ and ASE-extracted sample (1 mL plus $4 \mathrm{~mL}$ deionized water) were mixed with a $10 \mathrm{~mL}$ scintillation cocktail. An external standard was used for quenching correction using $5 \mathrm{~mL}$ of distilled water with $10 \mathrm{~mL}$ of scintillation cocktail.

\section{Non-extractable residues}

The ${ }^{14} \mathrm{C}$ activity remaining in the soil of the Microcosms 1, 2, 3 and 4 after ASE-extraction was referred to as non-extractable ${ }^{14} \mathrm{C}$ residue. The ${ }^{14} \mathrm{C}$ activity remaining in the straw of Microcosms 3 and 5 after the water extraction was referred to as non-water-extractable ${ }^{14} \mathrm{C}$ residue. The non-extractable and non-waterextractable ${ }^{14} \mathrm{C}$ residues were determined using three replicates containing $0.5 \mathrm{~g}$ dry weight of soil and $0.1 \mathrm{~g}$ dry weight of straw, respectively. Samples were weighed in porcelain vials and combusted using a biological oxidizer. The ${ }^{14} \mathrm{CO}_{2}$ produced was trapped in the scintillation cocktail and analyzed by LSC. The mass balance of ${ }^{14} \mathrm{C}$ was determined by summing the ${ }^{14} \mathrm{CO}_{2}$ evolved during mineralization, the ${ }^{14} \mathrm{C}$ activity in water and ASE extracts, and the ${ }^{14} \mathrm{CO}_{2}$ recovered from the combusted samples. A mass balance between $77 \%$ and $100 \%$ was obtained.

\section{LC-MS/MS analysis}

ATZ and its metabolites were identified and quantified in water and ASE extracts by means of LC-MS/MS equipped with an autosampler. The standards for ATZ, and its metabolites hydroxyatrazine [2-hydroxy-4-ethylamino-6-isopropylamino-s-triazine (HA), 96 \%], desethylatrazine [2-chloro-4-amino-6-isopropylamino-s-triazine (DEA), $100 \%$ ], and deisopropylatrazine [2-chloro-4-ethylamino-6-amino-s-triazine (DIA), 96 \%] were purchased from Riedel-de Haën. Deuterated ATZ and its metabolites were used as internal standards in a concentration of $0.01 \mu \mathrm{g} \mathrm{mL}^{-1}$. Water and ASE extracts (100 $\mu \mathrm{L}$ of each) were mixed with $40 \mu \mathrm{L}$ of deuterated standard solution. The solid phase $(2.1 \mathrm{~mm} \times 125 \mathrm{~mm} \times 3 \mu \mathrm{m})$ was used with an additional LC precolumn $(2.1 \mathrm{~mm} \times 10 \mathrm{~mm}$ $\times 3 \mu \mathrm{m})$. Solutions of $0.1 \mathrm{mmol} \mathrm{L}^{-1}$ ammonium acetate (Merck) in deionized water and acetonitrile (Biosolve) were used as LC eluents in a gradient elution mode. The flow rate was $0.15 \mathrm{~mL} \mathrm{~min}^{-1}$ at a column temperature of $25^{\circ} \mathrm{C}$. The injection was performed in triplicate, and the total injection volume of each sample was $10 \mu \mathrm{L}$. LC-MS/ MS analyses were performed in a positive electrospray ionization source (ESI +), and transitions were measured in multiple reaction monitoring (MRM). The settings for the analysis and mass transfer of ATZ metabolites were based on Jablonowski et al. (2008). The analytical detection limit and retention time were, respectively, $0.03 \mathrm{ng}$ $\mathrm{mL}^{-1}$ and $17.44 \mathrm{~min}$ for ATZ, $0.04 \mathrm{ng} \mathrm{mL}^{-1}$ and 13.61 min for HA, $0.7 \mathrm{ng} \mathrm{mL}^{-1}$ and $14.58 \mathrm{~min}$ for DIA, and 0.4 $\mathrm{ng} \mathrm{mL}^{-1}$ and $13.46 \mathrm{~min}$ for DEA.

\section{Data analysis}

The whole ATZ mineralization data from Microcosms 1 and 4 did not fit a zero, first or second-order degradation kinetic model. However, the data, when divided into two consecutive segments, fitted a first- 
order degradation kinetic model $\left[\mathrm{Y}=A_{0} \times\left(1-\mathrm{e}^{-k t}\right)\right]$. In this equation, $A_{0}$ is the maximum amount of evolved ${ }^{14} \mathrm{CO}_{2}$ (\% of added radioactivity), $k$ the mineralization rate constant $\left(\mathrm{d}^{-1}\right)$ and $t$ the time (days). A mineralization rate lower than $1 \%$ of applied ${ }^{14} \mathrm{C}$-ATZ $\mathrm{d}^{-1}$ was considered as the dividing point between the two segments of the curve. The half-life $\left(t_{1 / 2}\right)$ value for ATZ was calculated from the relationship $t_{1 / 2}=\ln 2 / k$. Data from Microcosms 2 and 3 were fitted to a zero-order degradation kinetic model $\left[\mathrm{Y}=-k \times t+C_{0}\right]$, where $C_{0}$ is the initial amount of applied radioactivity, and the half-life value for ATZ was calculated from the relationship $t_{1 / 2}$ $=\mathrm{C}_{0} / 2 k$. However, due to minor ${ }^{14} \mathrm{C}$-ATZ mineralization in these two Microcosms within the experimental time, the values for ATZ half-lives based on ${ }^{14} \mathrm{C}-\mathrm{ATZ}$ mineralization data were not appropriate (Jablonowski et al., 2010; Martinazzo et al., 2010). Therefore, the estimated half-lives for Microcosms 2 and 3 will not be presented nor discussed.

Statistical analysis consisted of the application of an independent two-sample $t$ test in order to compare the means as follows: cultivated soil (Microcosm 1) versus native soil (Microcosm 2), cultivated soil with straw cover (Microcosm 3) versus cultivated soil without straw cover (Microcosm 4), and straw of Microcosm 3 versus straw of Microcosm 5, at each sampling date. Treatment effects were considered significant at $p<0.05$. All statistical analysis was performed using SAS (Statistical Analysis System, version 9.3).

\section{Results and Discussion}

\section{ATZ mineralization}

Figure $1 \mathrm{~A}$ shows the cumulative ${ }^{14} \mathrm{CO}_{2}$ results. Data showed differences $(p<0.05)$ in ATZ mineralization between the cultivated soil (Microcosm 1) and the native soil (Microcosm 2) throughout the entire incubation period. By the end of the experiment, Microcosm 1 presented ATZ mineralization (86 \%) higher than Microcosm $2(10 \%)$. By day 12 of incubation, only 25 $\%$ of the applied radioactivity remained in Microcosm 1 , showing the occurrence of rapid ATZ degradation in the cultivated soil. Enhanced biodegradation of ATZ was reported in a heavy clayey subtropical Rhodic Hapludox cropped with maize under no-tillage from the south of Brazil where ATZ mineralization reached $82 \%$ by day 85 of incubation (Martinazzo et al., 2010). In the same study, a different pattern with a clayey Xanthic Haplustox from northeastern Brazil was observed, where, in addition to a lag phase of about 7 days, approximately $74 \%$ of the initially applied ${ }^{14} \mathrm{C}$-ATZ was mineralized by the end of the incubation period. Results from this study, together with data from other authors indicated that, in addition to the history of herbicide application (Bonfleur et al., 2010), physical and chemical properties of the soil (Dick et al., 2010), local environmental conditions, such as rainfall (Correia et al., 2007), topography (Aquino et al., 2013) and agricultural practices, such as straw
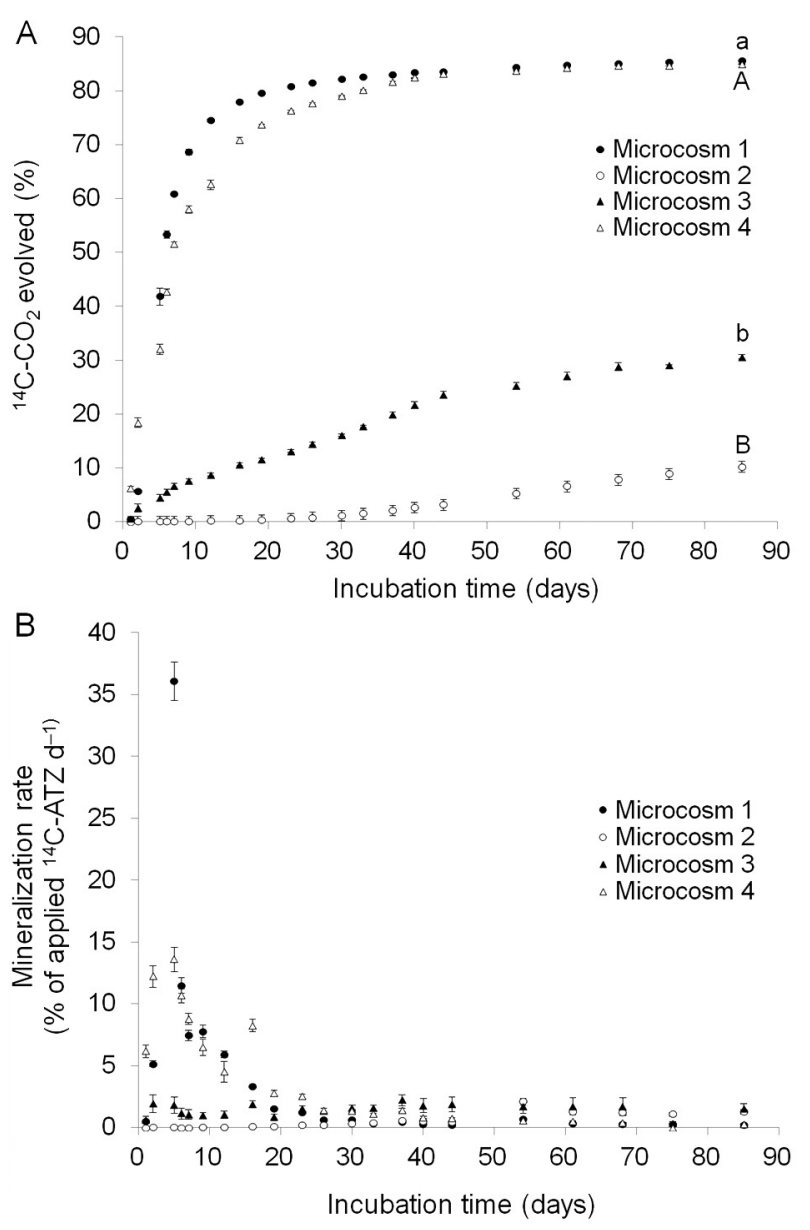

Figure 1 - Cumulative ${ }^{14} \mathrm{CO}_{2}(\mathrm{~A})$ and rates of ${ }^{14} \mathrm{C}$-ATZ mineralization (B) during laboratory incubations in the cultivated soil (Microcosm 1), in the native soil (Microcosm 2), in the cultivated soil covered with straw (Microcosm 3) and with no straw cover (Microcosm 4). Different upper case letters indicate significant differences between Microcosm 1 and Microcosm 2; different lower case letters indicate significant differences between Microcosm 3 and Microcosm 4, on day 85 of incubation ( test, $p<0.05$ ). The error bars represent the standard deviation of the mean. $n=3$.

cover (Amadori et al., 2016) and the addition of organic residues (Silva et al., 2016) may also affect the extent of ATZ dissipation.

Concerning the role of cover straw, data showed differences $(p<0.05)$ in ATZ mineralization between the cultivated soil when covered with straw (Microcosm 3) and with no straw cover (Microcosm 4) throughout the incubation period (Figure 1A). The presence of straw on the soil surface reduced ATZ mineralization from 85 $\%$ (Microcosm 4) to $31 \%$ (Microcosm 3) by day 85 of incubation. It was concluded that the straw most likely acted as a physical barrier and prevented the herbicide from reaching the soil where it would be degraded by the adapted microorganisms. Interestingly, the cultivated soil was submitted to two methods of ATZ application, 
mixing (Microcosm 1) and dropping (Microcosm 4), and in both Microcosms ATZ mineralization reached values of up to $85 \%$.

Figure $1 \mathrm{~B}$ shows the mineralization rate results. By day 5 of incubation, the mineralization rate had reached its maximum, corresponding to a mineralization of $36 \%$ and $14 \%$ of the applied ${ }^{14} \mathrm{C}-\mathrm{ATZ} \mathrm{d} \mathrm{d}^{-1}$ in Microcosms 1 and 4 , respectively. Thereafter, the mineralization rate decreased to $1 \% \mathrm{~d}^{-1}$ by days 26 and 40 of incubation in Microcosms 1 and 4, respectively, and then remained fairly constant until the end of the experiment. In contrast, the mineralization rate in the native soil (Microcosm 2) and in the cultivated soil with straw cover (Microcosm 3) did not exceed values of $2 \% \mathrm{~d}^{-1}$. In Microcosms 1 and 4 with cultivated bare soil, the experimental data were fitted to two consecutives segments of a firstorder kinetic model indicating the occurrence of two degradation kinetics within the incubation period. Regardless of the application mode, no latency time in overall mineralization was observed in the cultivated bare soil. In Microcosm 1, an initial fast degradation occurred by day 26 of incubation when $82 \%$ of the applied ATZ had been mineralized. The estimated half-life of this phase, estimated purely from the mineralization data, was 10 days. In Microcosm 4, faster degradation kinetics occurred by 43 days of incubation when $82 \%$ of the applied ATZ had been mineralized with an estimated half-life of 16 days. In both microcosms, the estimated half-life of the second degradation phase was 154 days. This degradation pattern may be related to the decrease in carbon sources throughout the incubation period by soil adapted microorganisms (Arbeli and Fuentes, 2007). However, a greater half-life than that calculated for the cultivated bare soil (Microcosms 1 and 4) was expected due to the lack of efficient degrading microorganisms in the native soil and also due to the physical barrier offered by the straw. The half-lives obtained in the present study for the faster degradation phase are in the same order of magnitude as the values obtained in other Brazilian Oxisols that varied between 4 and 51 days (Martinazzo et al., 2010; Silva et al., 2016).

\section{Extractable and non-extractable ${ }^{14} \mathrm{C}$-ATZ residues}

Figures $2 \mathrm{~A}$ and $\mathrm{B}$ show the water-extractable and ASE-extractable ${ }^{14} \mathrm{C}$ residues and results, respectively, obtained in Microcosms 1 and 2. Data showed differences $(p<0.05)$ in the amount of ${ }^{14} \mathrm{C}$ residues between the cultivated soil (Microcosm 1) and the native soil (Microcosm 2) throughout the incubation time. Microcosm 2 presented higher amounts of waterextractable and ASE-extractable ${ }^{14} \mathrm{C}$ residues than Microcosm 1, except on the first day of sampling. Microcosm 1 presented an amount of water-extractable ${ }^{14} \mathrm{C}$ residues of $69 \%$ directly after ATZ application (day 0) (Figure 2A). This value decreased drastically to about $7 \%$ on day 9 of incubation, and had reached $1 \%$ by the end of the incubation period. The amount of ASEextractable ${ }^{14} \mathrm{C}$ residues in Microcosm 1 varied from 16
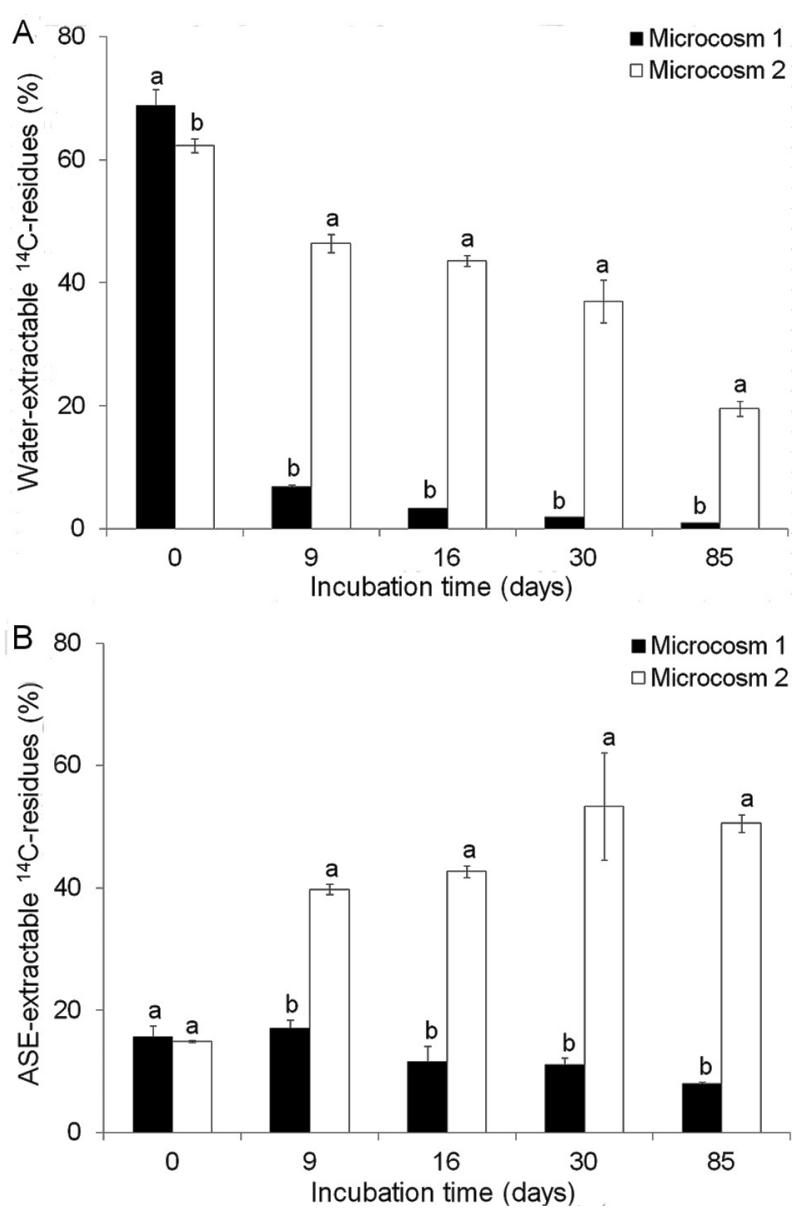

Figure 2 - Water-extractable ${ }^{14} \mathrm{C}$ residues (A) and accelerated solvent extraction (ASE)-extractable ${ }^{14} \mathrm{C}$ residues (B) in the cultivated soil (Microcosm 1) and in the native soil (Microcosm 2). Non-extractable ${ }^{14} \mathrm{C}$ residues were approximately $0 \%$ and do not appear. Values are reported as percentages of total ${ }^{14} \mathrm{C}$ applied activity as a function of time. Different letters indicate significant differences of the water-extractable and ASE-extractable ${ }^{14} \mathrm{C}$ residues between the microcosms at a given sampling date ( $t$ test, $p<0.05)$. The error bars represent the standard deviation of the mean. $n=3$.

$\%$ to $8 \%$ during the 85 days (Figure $2 \mathrm{~B}$ ). Non-extractable ${ }^{14} \mathrm{C}$ residues were not detected in the cultivated soil. This pattern of ${ }^{14} \mathrm{C}$ residue formation was somewhat expected because of the rapid mineralization of ATZ observed in the soil with a history of ATZ application, as shown in Figure 1A. In contrast, in Microcosm 2, the amount of water-extractable ${ }^{14} \mathrm{C}$ residues decreased more slowly over time (from $62 \%$ to $20 \%$ ) (Figure 2A), and there was a concomitant increase in the ASE-extractable ${ }^{14} \mathrm{C}$ residues from $15 \%$ to $51 \%$ (Figure 2B). The amount of non-extractable ${ }^{14} \mathrm{C}$ residues was about $0 \%$ in this microcosm (data not shown). Considering the low ATZ mineralization obtained in the native soil $(10 \%)$ and the amounts of ${ }^{14} \mathrm{C}$ residues throughout the incubation 
period, it appeared that ATZ and its metabolites were mainly transferred from the more accessible soil compartment (water-extractable) to a less accessible one (ASE-extractable) as a result of its degradation. These results indicated the occurrence of an aging process of ATZ in the soil, characterized by a stronger bonding of the compound with soil components over time and a decrease in its bioavailability (Gevão et al., 2003).

Figures $3 \mathrm{~A}, \mathrm{~B}$ and $\mathrm{C}$ show the water-extractable, ASE-extractable and non-extractable ${ }^{14} \mathrm{C}$ residue results, obtained in Microcosms 3 and 4, respectively. Data showed differences $(p<0.05)$ in the amount of extractable and non-extractable ${ }^{14} \mathrm{C}$ residues between the cultivated soil when covered with straw (Microcosm 3) and with no straw cover (Microcosm 4) for the entire incubation period. Microcosm 4 presented an amount of water-extractable ${ }^{14} \mathrm{C}$ residue greater than Microcosm 3 only on the first day of sampling $(82 \%$ and $23 \%$, respectively). In Microcosm 4 the amount of water-extractable ${ }^{14} \mathrm{C}$ residues rapidly decreased to $9 \%$ by day 9 of incubation, reaching $10 \%$ by day 85 of incubation (Figure $3 \mathrm{~A}$ ). Microcosm 4 also presented a higher amount of ASEextractable ${ }^{14} \mathrm{C}$ residues than Microcosm 3 on days 0 , 16 and 30 of incubation. In Microcosm 4 the amount of ASE-extractable ${ }^{14} \mathrm{C}$ residues decreased from $24 \%$ to 9 $\%$ (Figure 3B), whilst the amount of non-extractable ${ }^{14} \mathrm{C}$ residues was approximately $5 \%$ during the incubation period (Figure 3C). As regards Microcosm 3, the amount of water-extractable ${ }^{14} \mathrm{C}$ residues decreased from $23 \%$ to $8 \%$ (Figure $3 \mathrm{~A}$ ), whilst those of ASE-extractable ${ }^{14} \mathrm{C}$ residues increased from $4 \%$ to $11 \%$ (Figure $3 \mathrm{~B}$ ), during the incubation period. Moreover, by the end of the experiment, the amount of non-extractable ${ }^{14} \mathrm{C}$ residues (Figure 3C) was higher in Microcosm $3(7 \%)$ than in Microcosm 4 (4\%). On days 0 and 85 of incubation, the sum of the three ATZ compartments (water-extractable, ASE-extractable and non-extractable) in the soil of Microcosm 3 was $28 \%$ and $26 \%$, respectively. These results indicated that in the soil covered with straw, ATZ was redistributed from the more accessible compartment (water-extractable) to a less accessible one (ASEextractable and non-extractable) during the incubation period. Considering that solvent accessibility to a given ATZ soil compartment may be related to its accessibility to biodegradation or its uptake, it therefore follows that the residues in the soil tended to be less susceptible to biodegradation throughout the incubation period.

Figure 4 shows the water-extractable and nonwater-extractable ${ }^{14} \mathrm{C}$ residue results obtained from Microcosms 3 and 5. The measurements of ${ }^{14} \mathrm{C}$ residues were taken only on days 0 and 85 of incubation in Microcosm 5. Therefore, there is no statistical analysis between Microcosm 3 and Microcosm 5 on days 9, 16 and 30 of incubation. Data showed differences $(p<0.05)$ in the amount of ${ }^{14} \mathrm{C}$ residue between the straw cover of cultivated soil (Microcosm 3) and solely straw cover alone (Microcosm 5) on days 0 and 85 of incubation. In the case of the straw cover alone (Microcosm 5) there
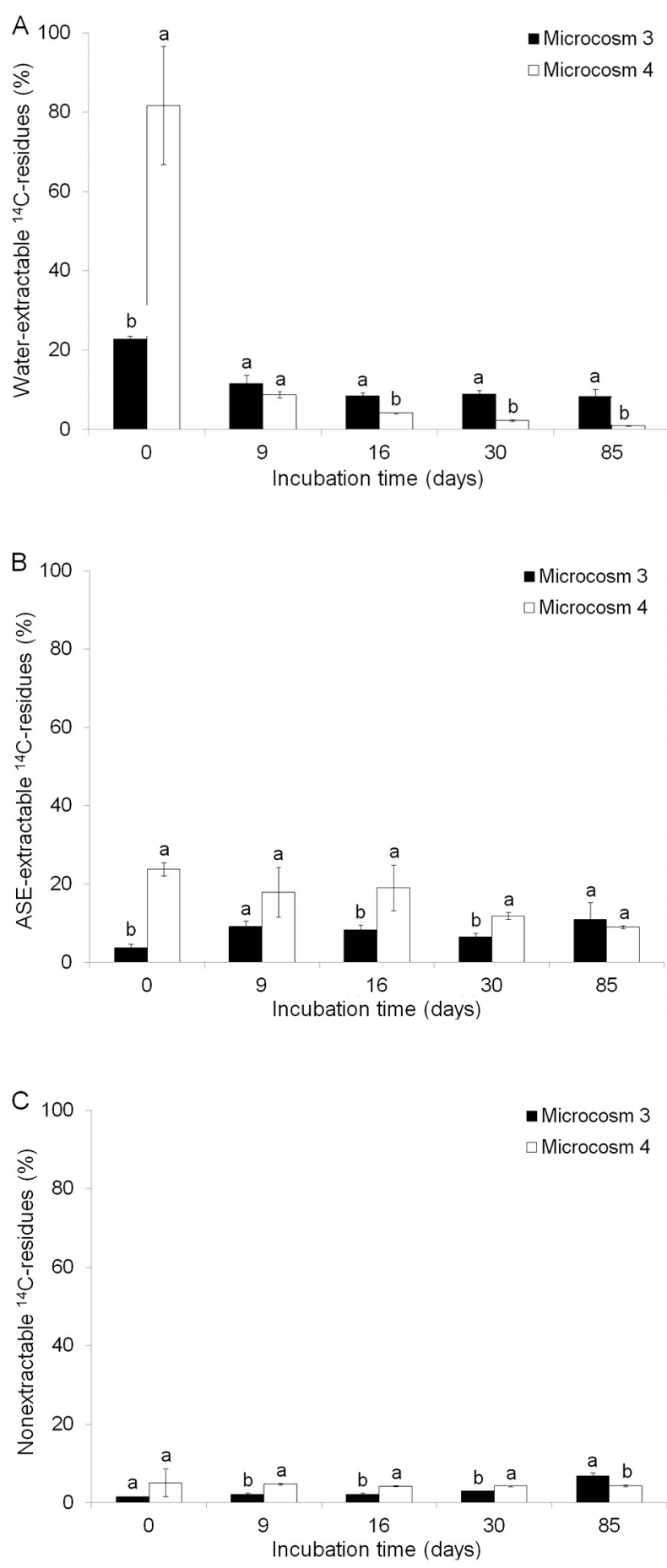

Figure 3 - Water-extractable (A), ASE-extractable (B) and nonextractable $(C){ }^{14} \mathrm{C}$ residues in the cultivated soil covered with straw (Microcosm 3) and with no straw cover (Microcosm 4). Values are reported as percentages of total ${ }^{14} \mathrm{C}$ applied activity as a function of time. Different letters indicate significant differences in the water-extractable, ASE-extractable and non-extractable ${ }^{14} \mathrm{C}$ residues between the microcosms on a given sampling date $(t$ test, $p<0.05)$. The error bars represent the standard deviation of the mean. $n=3$. 


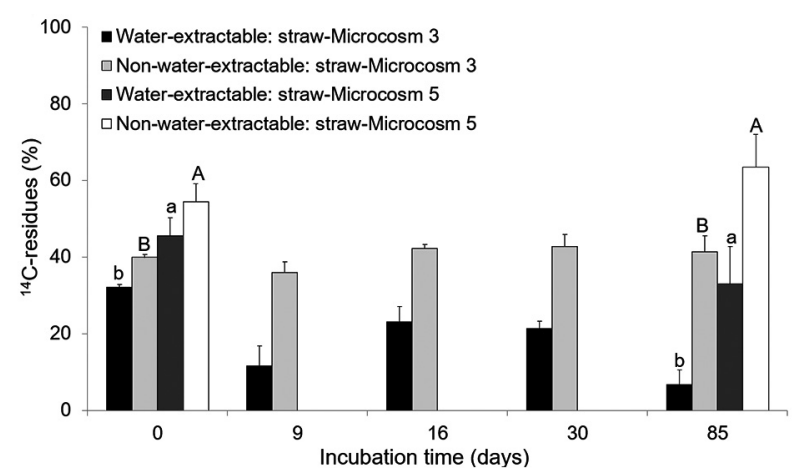

Figure 4 - Water-extractable and non-water-extractable ${ }^{14} \mathrm{C}$ residues in the straw cover of Microcosm 3 and in the straw of Microcosm $5 .{ }^{14} \mathrm{C}$ residues were extracted only on days 0 and 85 of incubation in Microcosm 5. Values are reported as percentages of total ${ }^{14} \mathrm{C}$ applied activity as a function of time. Different upper case letters indicate significant differences of the non-water-extractable ${ }^{14} \mathrm{C}$ residues between microcosms; different lower case letters denote significant differences in the water-extractable ${ }^{14} \mathrm{C}$ residues between microcosms, at a given sampling date ( $t$ test, $p<0.05$ ). The error bars represent the standard deviation of the mean; $n=3$.

were higher amounts of water-extractable and nonwater-extractable ${ }^{14} \mathrm{C}$ residue when compared with the straw cover of the cultivated soil (Microcosm 3) on both sampling dates. In the straw cover of Microcosm 3, the amount of water-extractable ${ }^{14} \mathrm{C}$ residue ranged from 32 $\%$ on day 0 to $7 \%$ of the applied ${ }^{14} \mathrm{C} \mathrm{ATZ}$ on day 85 of incubation; whilst that of the non-water-extractable residue remained fairly constant oscillating around 40 \%. In Microcosm 5, where straw was incubated in the absence of soil, the amount of water-extractable ${ }^{14} \mathrm{C}$ residue ranged from $46 \%$ to $33 \%$; and, the amount of non-water-extractable ${ }^{14} \mathrm{C}$ residue from $54 \%$ to 64 $\%$ during incubation. Furthermore, the sum of the amounts of the two compartments approached $100 \%$ of the applied ATZ both on day 0 of incubation as well as on day 85. It therefore followed that no relevant ATZ mineralization (data not shown) occurred in the case of the straw cover alone (Microcosm 5). In fact, an aging process of the herbicide was observed only where it migrated to a less accessible/stronger bound form. Therefore, ATZ mineralization in Microcosm 3 may have occurred at the expense of the water-extractable ${ }^{14} \mathrm{C}$ residue in the straw cover, which was gradually transferred to the soil, where it was then degraded by the soil-adapted microorganisms (Figures 1A, 3A and 4).

\section{Extractable ATZ and its metabolites}

Figures 5A, B, C, D, E and F show the extractable ATZ and its metabolite results. The extractable ATZ and its metabolites were considered as a whole (water-extractable + ASE-extractable residues) and discussed as a proportion of the total amount extracted on each sampling date. In the water and ASE extracts, only the metabolites
HA and DEA were detected. These two residues are considered the most relevant ATZ metabolites and they result from ATZ hydrolysis (HA) and N-dealkylation of the ATZ side chains (DEA) (Mudhoo and Garg, 2011).

Figure 5A, C and D show extractable ATZ and its metabolites in the microcosms with cultivated soil (Microcosms 1, 3 and 4). In general, in the cultivated soil ATZ concentration ranged from $80 \%$ to $94 \%$ on day 0 of incubation and dropped to values between $2 \%$ and $19 \%$ on day 85 of incubation. The decrease in ATZ concentration was accompanied by an increase in its extractable metabolites. As expected, a greater amount of HA was observed in comparison to DEA. At the end of the incubation period, the amount of HA varied between $78 \%$ and $97 \%$; whilst that of DEA ranged from $2 \%$ in Microcosms 1 and 4 to $10 \%$ in Microcosm 3. This pattern indicated the occurrence of chemical hydrolysis and presence of microbial communities which degrade ATZ into hydroxylated derivatives and dealkylated metabolites, respectively (Sene et al., 2010). Similar findings of ${ }^{14} \mathrm{C}$ ATZ degradation (mainly into HA) have been reported for other Brazilian soils (Martinazzo et al., 2010; Peixoto et al., 2000; Prata et al., 2003).

Figure $5 \mathrm{~B}$ shows the extractable ATZ and its metabolites in the native soil (Microcosm 2). ATZ concentration decreased from $78 \%$ to $64 \%$; HA concentration increased from $22 \%$ to $32 \%$, and DEA concentration reached $4 \%$ during the incubation period. Both mineralization and metabolization of ATZ (Figures 1A and $5 \mathrm{~B}$, respectively) were comparatively lower in the native soil. Nevertheless, the low ATZ mineralization (10 $\%)$ and this partial degradation of ATZ into HA (32 \%) and DEA $(4 \%)$ in the native soil indicated the presence of soil microbiota capable of degrading ATZ. The presence of $0.3 \mu \mathrm{g} \mathrm{kg}^{-1}$ of $\mathrm{HA}$ detected in the native soil (Table 1) is most probably attributable to a previous contamination during its application in neighboring cultivated areas, whilst the agricultural use of pesticides may result in some loss of the applied compound even before it reaches the soil (Casara et al., 2012; Thurman and Cromwell, 2000). Nevertheless, the possibility of an abiotic formation of HA should not be discarded, since the studied soils presented $\mathrm{pH}$ levels (Table 1) that could favor the formation of hydroxylated derivatives to the detriment of DEA and DIA (Loiseau and Barriuso, 2002), which were not detected at this time.

Figures $5 \mathrm{E}$ and $\mathrm{F}$ show the extractable ATZ and metabolites in the straw of both Microcosm 3 and Microcosm 5, respectively. In the straw extracts of Microcosm 3, ATZ was the most abundant extractable compound until day 30 of incubation (> $85 \%$ ), decreasing drastically and by day 85 of incubation it represented only $12 \%$ of the extractable residues (Figure 5E). At the end of the incubation period, the HA proportion was 77 $\%$ and that of DEA was $10 \%$ of the extractable residues. The same pattern was observed for the straw from Microcosm 5 (Figure 5F). By day 85 of incubation, ATZ, HA and DEA concentrations had reached $24 \%, 73 \%$ and $4 \%$, 

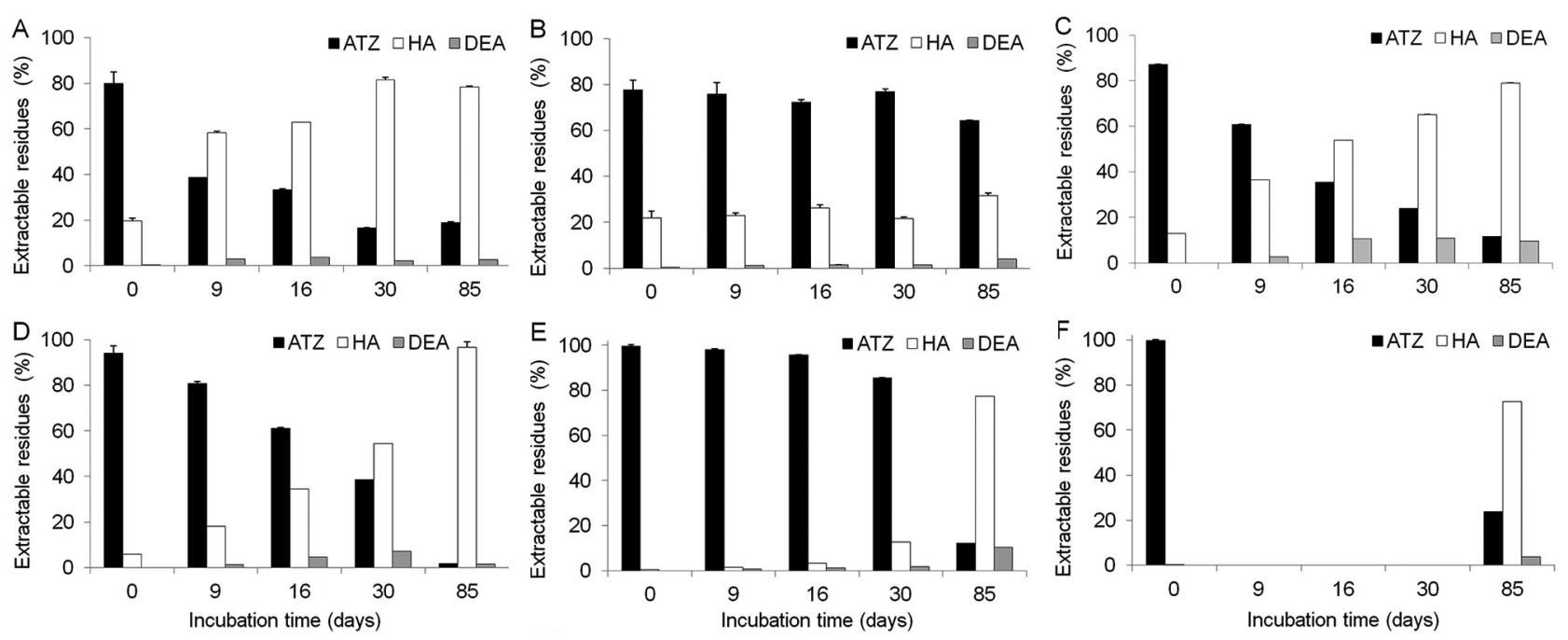

Figure 5 - Proportion of extracted atrazine (ATZ), hydroxyatrazine (HA) and desethylatrazine (DEA) in relation to the total amount extracted within 85 days of incubation in the cultivated soil (Microcosm 1) (A), in the native soil (Microcosm 2) (B), in the cultivated soil covered with straw (Microcosm 3) (C) and with no straw cover (Microcosm 4) (D), in the straw cover on the cultivated soil (Microcosm 3) (E) and in the straw (Microcosm 5) (F). The error bars represent the standard deviation of the mean; $n=3$.

respectively. Regarding ATZ retention in straw and its formation of metabolites, a previous experiment performed in a maize field in Brazil (Paraná State) reported ATZ concentrations two-fold higher in comparison to DEA and DIA even after 180 days of ATZ application (Amadori et al., 2016). Degradation of ATZ into its metabolites observed in the straw from Microcosms 3 and 5 may also have been caused by fungi, since the presence of fungal colonies in both microcosms were visible to the naked eye. Sene et al. (2010) described that ATZ biodegradation is mainly due to bacteria, but it has also been observed in a number of fungi species. The authors also reported on previous incubation experiments with fungi, in which the biodegradation of ATZ resulted in the accumulation of hydroxylated and/or N-dealkylated metabolites and no mineralization of the ring- ${ }^{14} \mathrm{C}$-labeled ATZ.

\section{Conclusion}

The cultivated Typic Paleudult evaluated in this study presented greater ATZ mineralization ( 8.6 fold) and metabolization ( 2.2 fold) as compared with the native soi that was assigned to the adaptation of the soil microorganisms to the herbicide. This behavior is positive from an environmental standpoint but negative with regard to weed control. The straw cover on the soil surface decreased ATZ contact with the soil and thus its access to the ATZ-degrading microorganisms. As a result, overall ATZ mineralization in this system was also reduced. In the straw, ATZ was either transferred to a less accessible compartment or transformed, probably abiotically, into $\mathrm{HA}$ at the very end of the incubation period. Information about the sorption and leaching of herbicides from straw cover is needed to prevent the increase in herbi- cide application frequency in order to overcome the dissipation of ATZ due to these two mechanisms.

\section{Acknowledgments}

The corresponding author is grateful for support from the Coordenação de Aperfeiçoamento de Pessoal de Nivel Superior (CAPES), the Conselho Nacional de Desenvolvimento Científico e Tecnológico (CNPQ) and the German Academic Exchange Service (DAAD). Thanks are due to Ulrike Langen and Martina Krause for their excellent technical assistance.

\section{Authors' Contributions}

Conceptualization: Leal, D.P.B., Dick, D.P., Burauel, P. Data acquisition: Leal, D.P.B., Stahl, A.M., Köppchen, S. Data analysis: Leal, D.P.B., Dick, D.P., Köppchen, S., Burauel, P. Design of methodology: Leal, D.P.B., Dick, D.P., Burauel, P. Writing and editing: Leal, D.P.B., Dick, D.P., Burauel, P.

\section{References}

Alvares, C.A.; Stape, J.L.; Sentelhas, P.C.; Gonçalves, J.L.M.; Sparovek, G. 2013. Köppen's climate classification map for Brazil. Meteorologische Zeitschrift 22: 711-728.

Amadori, M.F.; Rodrigues, M.B.; Rebouças, C.C.; Peralta-Zamora, P.G.; Grassi, M.T.; Abate, G. 2016. Behavior of atrazine and its degradation products deethylatrazine and deisopropylatrazine in Oxisol samples. Water, Air and Soil Pollution 227: 380.

Araldi, R.; Velini, E.D.; Gomes, G.L.G.C.; Tropaldi, L.; Silva, I.P.F.; Carbonari, C.A. 2015. Performance of herbicides in sugarcane straw. Ciência Rural 45: 2106-2112. 
Arbeli, Z.; Fuentes, C.L. 2007. Accelerated biodegradation of pesticides: an overview of the phenomenon, its basis and possible solutions; and a discussion on the tropical dimension. Crop Protection 26: 1733-1746.

Aquino, R.F.; Lima, J.M.; Magalhães, C.A.S.; Silva, B.M.; Carvalho, R.F.; Guilherme, L.R.G. 2013. Atrazine in a corn cultivated area and its relation with the landscape position. Ciência e Agrotecnologia 37: 389-396.

Bonfleur, E.J.; Lavorenti, A.; Tornisielo, V.L. 2010. Mineralization and degradation of glyphosate and atrazine applied in combination in a Brazilian Oxisol. Journal of Environmental Science and Health. Part B 46: 69-75.

Casara, K.P.; Vecchiato, A.B.; Lourencetti, C.; Pinto, A.A.; Dores, E.F.G.C. 2012. Environmental dynamics of pesticides in the drainage area of the São Lourenço river headwaters, Mato Grosso state, Brazil. Journal of the Brazilian Chemical Society 23: 1719-1731.

Companhia Nacional de Abastecimento [CONAB]. 2017. Follow up of the Brazilian grains crop, crop 2016/2017: eighth assessment $=$ Acompanhamento da safra Brasileira grãos, safra 2016/2017: oitavo levantamento. CONAB, Brasília, DF, Brazil. Available at: http://www.conab.gov.br/OlalaCMS/uploads/ arquivos/17_05_12_10_37_57_boletim_graos_maio_2017.pdf [Accessed May 30, 2017] (in Portuguese).

Conselho Nacional do Meio Ambiente [CONAMA]. 2005. Resolution n. 357, from March 17, 2015 = Resolução n. 357, de 17 de março de 2005. Ministério do Meio Ambiente, Brasília, DF, Brazil. Available at: http://www.mma.gov.br/port/conama/ res/res05/res35705.pdf [Accessed May 30, 2017] (in Portuguese).

Corbeels, M.; Marchão, R.L.; Neto, M.S.; Ferreira, E.G.; Madari, B.E.; Scopel, E.; Brito, O.R. 2016. Evidence of limited carbon sequestration in soils under no-tillage systems in the Cerrado of Brazil. Scientific Report 6: 21450. Available at: http://www. nature.com/articles/srep21450 [Accessed Oct 21, 2016]

Correia, F.V.; Macrae, A.; Guilherme, L.R.G.; Langenbach, T. 2007. Atrazine sorption and fate in a Ultisol from humid tropical Brazil. Chemosphere 67: 847-854.

Dick, D.P.; Martinazzo, R.; Knicker, H.; Almeida, P.S.G. 2010. Organic matter in four Brazilian soil types: chemical composition and atrazine sorption. Química Nova 33: 14-19 (in Portuguese, with abstract in English).

Gan, J.; Papiernik, S.K.; Koskinen, W.C.; Yates, S.R. 1999. Evaluation of accelerated solvent extraction (ASE) for analysis of pesticide residues. Environmental Science and Technology 33: 3249-3253.

Gevão, B.; Jones, K.C.; Semple, K.T.; Craven, A.; Burauel, P. 2003. Non-extractable pesticide residues in soil: how can we resolve conflicts in definition, regulatory requirements, and significance? Environmental Science and Technology 37: 138-144.

Jablonowski, N.D.; Borchard, N.; Zajkoska, P.; Fernández-Bayo, J.D.; Martinazzo, M.; Berns, A.; Burauel, P. 2013 Biocharmediated [14C]atrazine mineralization in atrazine-adapted soils from Belgium and Brazil. Journal of Agricultural and Food Chemistry 61: 512-516.

Jablonowski, N.D.; Hamacher, G.; Martinazzo, R.; Langen, U.; Koeppchen, S.; Hofmann, D.; Burauel, P. 2010. Metabolism and persistence of atrazine in several field soils with different atrazine application histories. Journal of Agricultural and Food Chemistry 58: 12869-12877.
Jablonowski, N.D.; Koeppchen, S.; Hofmann, D.; Schaeffer, A.; Burauel, P. 2009. Persistence of ${ }^{14} \mathrm{C}$-labeled atrazine and its residues in a field lysimeter soil after 22 years. Environmental Pollution 157: 2126-2131.

Jablonowski, N.D.; Koeppchen, S.; Hofmann, D.; Schaeffer, A.; Burauel, P. 2008. Spatial distribution and characterization of long-term aged ${ }^{14} \mathrm{C}$-labeled atrazine residues in soil. Journal of Agricultural and Food Chemistry 56: 9548-9554.

Krutz, J.L.; Shaner, D.L.; Weaver, M.A.; Webb, R.M.; Zablotowicz, R.M.; Reddy, K.N.; Huang, Y.; Thomson, S.J. 2010. Agronomic and environmental implications of enhanced s-triazine degradation. Pest Management Science 66: 461-481.

Loiseau, L.; Barriuso, E. 2002. Characterization of the atrazine's bound (non extractable) residues using fractionation techniques for soil organic matter. Environmental Science \& Technology 36: 683-689.

Martinazzo, R.; Jablonowski, N.D.; Hamacher, G.; Dick, D.P.; Burauel, P. 2010. Accelerated degradation of ${ }^{14} \mathrm{C}$-atrazine in Brazilian soils from different regions. Journal of Agricultural and Food Chemistry 58: 7864-7870.

Mudhoo, A.; Garg, V.K. 2011. Sorption, transport and transformation of atrazine in soils, minerals and composts: a review. Pedosphere 21: 11-25.

National Center for Biotechnology Information [NCBI]. 2017. PubChem compound database. Available at: https://pubchem. ncbi.nlm.nih.gov/compound [Accessed June 03, 2017]

Nogueira, E.N.; Dores, E.F.G.C.; Pinto, A.A.; Amorim, R.S.S.; Ribeiro, M.L.; Lourencetti, C. 2012. Currently used pesticides in water matrices in central-western Brazil. Journal of the Brazilian Chemical Society 23: 1476-1487.

Peixoto, M.F.S.P.; Lavorenti, A.; Regitano, J.B.; Tornisielo, V.L. 2000. Degradation and formation of ${ }^{14} \mathrm{C}$-atrazine bound residues in soils of the São Paulo state. Scientia Agricola 57: 147-151 (in Portuguese, with abstract in English).

Prata, F.; Lavorenti, A.; Vanderborght, J.; Burauel, P.; Vereecken, H. 2003. Miscible displacement, sorption and desorption of atrazine in a Brazilian Oxisol. Vadose Zone Journal 2: 728-738.

Santos, E.A.; Cruz, C.; Carraschi, S.P.; Silva, J.R.M.; Botelho, R.G.; Velini, E.D.; Pitelli, R.A. 2015. Atrazine levels in the Jaboticabal water stream (São Paulo state, Brazil) and its toxicological effects on the pacu fish Piaractus mesopotamicus. Archives of Industrial Hygiene and Toxicology 66: 73-82.

Sass, J.B.; Colangelo, A. 2006. European Union bans atrazine, while the United States negotiates continued use. International Journal of Occupational and Environmental Health 12: 260267.

Sene, L.; Converti, A.; Secchi, G.A.R.; Simão, R.C.G. 2010. New aspects on atrazine biodegradation. Brazilian Archives of Biology and Technology 53: 487-496.

Silva, R.O.; Scorza Jr., R.P.; Bonfá, M.R.L.; Campanari, M.F.Z.; Mendes, I.C. 2016. Degradation and sorption of fipronil and atrazine in Latossols with organic residues from sugarcane crop. Ciência Rural 46: 1172-1177.

Thurman, E.M.; Cromwell, A.E. 2000. Atmospheric transport, deposition, and fate of triazine herbicides and their metabolites in pristine areas at Isle Royale National Park. Environmental Science and Technology 34: 3079-3085. 